\title{
The Role of Visual Communication During Covid Pandemic 19
}

\section{Peranan Komunikasi Visual Semasa Pandemik Covid 19}

\author{
Hanafi Mohd Tahir ${ }^{1}$, Shahrel Nizar Baharom ${ }^{2}$, Mohd Shahril Abd Rashid ${ }^{3}$ \\ Graphics Designa and Digital Media Department, Faculty of Art and Design, Universiti Teknologi \\ MARA Perak Branch, Seri Iskandar Campus, \\ 32610 Seri Iskandar, Perak, Malaysia \\ Authors'email: 'hanaf185@uitm.edu.my, ${ }^{2}$ shahr169@uitm.edu.my, ${ }^{3}$ mohds370@uitm.edu.my
}

Published: 28 September 2020

\begin{abstract}
The process of progress and development of communication has begun over the centuries and through various phases of development over time according to the passage of time. Various methods have been developed to facilitate communication activities. The excitement and fun of communicating activities takes place as if there is no time limit. Communication is an important aspect to meet the needs of daily life. There are no terms rest, pause or 'sleep' for communication.
\end{abstract}

Keywords: Communication Development, Daily Needs

\begin{abstract}
ABSTRAK
Proses kemajuan dan perkembangan komunikasi telah bermula sejak berkurun lama dan melalui pelbagai fasa perkembangan dari masa ke semasa mengikut pengaliran zaman. Pelbagai kaedah telah terhasil untuk memudahkan aktiviti berkomunikasi. Kemeriahan dan keseronokan aktiviti berkomunikasi berlaku seolah-olah tiada had masa. Komunikasi menjadi aspek penting untuk memenuhi keperluan kehidupan seharian. Tiada istilah berehat, berhenti sebentar atau 'tidur' bagi komunikasi.
\end{abstract}

eISSN: 2550-214X (C) 2020. The Authors. Published for Idealogy Journal by UiTM Press. This is an Open Access article distributed under the terms of the Creative Commons Attribution-NonCommercial-NoDerivatives License (http://creativecommons.org/licenses/by-nc-nd/4.0/), which permits non-commercial re-use, distribution, and reproduction in any medium, provided the original work is properly cited, and is not altered, transformed, or built upon in any way.

\section{PENGENALAN}

\subsection{Sejarah Umum Komunikasi}

Menurut Syerif Nurhakim (2015), perkataan komunikasi berasal daripada bahasa latin iaitu communicare yang membawa maksud berbagi, menyampai berita, pesan, informasi dan perasaan kepada orang lain. Komunikasi merupakan suatu aktiviti interaksi penyampaian dan penerimaan maklumat yang berlaku di antara satu pihak penyampai dengan satu pihak penerima. David Crowley dan Paul Heyer (2011), menyatakan bahawa komunikasi adalah pertukaran informasi dan maklumat iaitu ianya suatu aktiviti yang telah dipraktikkan sekian lama dahulu menerusi pertuturan dan juga pelakuan isyarat.

Komunikasi bukan hanya terhad melalui pertuturan dan bahasa isyarat sahaja, ia juga dijalankan secara visual. Dahulu kala, manusia mula berkomunikasi di antara satu sama lain dengan bercerita dan berhubung secara terus. Manusia pada masa tersebut akan menggunakan apa juga kaedah yang dirasakan bersesuaian asalkan dapat menyampaikan ataupun menerima maklumat. Justeru itu, kaedah komunikasi menggunakan lakaran, contengan, huruf-huruf, imej serta simbol-simbol mula wujud dan 
berkembang dari masa ke semasa. Lukisan-lukisan dan lakaran-lakaran yang dikenali sebagai Piktograf dan Hieroglif mula wujud.

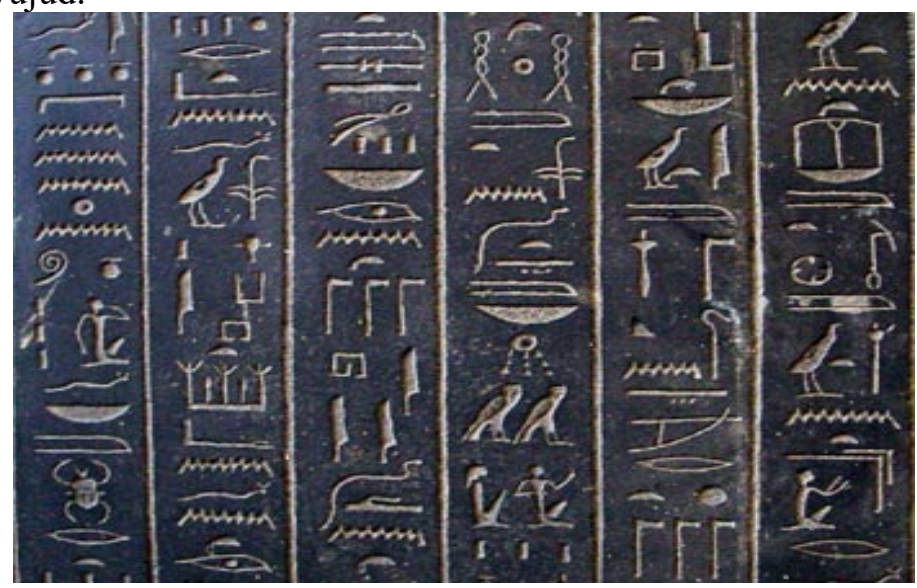

Rajah 1: Komunikasi visual pada zaman dahulu

Rajah 1 menunjukkan visual simbol dan lambang Hieroglif diperolehi daripada lorekan di permukaan batu. Lorekan tersebut menggambarkan maksud imej asal atau objek realiti sebenar. Ia secara asasnya adalah bertujuan untuk menyampaikan maklumat tertentu dan memudahkan manusia untuk memahami maksud penceritaan apabila melihatnya. Peter Dorman (2019) menyatakan bahawa visual Hieroglif perlu dilihat dengan teliti bagi memahami apakah jalan cerita yang hendak disampaikan.

\section{KOMUNIKASI VISUAL}

Komunikasi visual adalah suatu proses menyalurkan maklumat melalui visual. Ia melibatkan rekaan grafik seperti logo, animasi, ilustrasi, fotografi, warna, simbol, lambang, identiti korporat, pengiklanan, multimedia dan lain-lain hasil rekaan kreatif. Menurut Faridah (2012), komunikasi visual ialah konsep komunikasi dan ungkapan kreativiti yang melibatkan elemen-elemen reka bentuk grafik iaitu gambar, huruf, warna, komposisi dan paparan reka bentuk. Semasa seluruh negara di dunia bergelut dan berhadapan dengan pandemik Covid 19, komunikasi visual menjadi kaedah yang begitu hebat sekali dan digunakan secara meluas dalam menyampaikan maklumat. Komunikasi visual telah membantu orang ramai untuk mengenalpasti arahan, panduan serta tindakan yang perlu dilakukan untuk pengawalan serta penularan penyakit Covid 19. Banyak info-info grafik mengenai Covid 19 direka dan dihasilkan sebagai komunikasi visual bertujuan untuk mencapai objektif menjelaskan, mendidik serta memudahkan kefahaman. Kepentingan orang ramai memahami komunikasi visual amatlah penting agar maklumat sebenar yang disampaikan dapat dicapai. Suatu kajian yang dilakukan oleh Nur Idayu Yusi (2017), menyatakan kepentingannya literasi visual untuk pengajaran dan pembelajaran agar kefahaman terhadap visual dapat dicapai dengan baik.

\subsection{Komunikasi Visual Berperanan Untuk Menjelaskan}

Kementerian Kesihatan serta Majlis Keselamatan Negara mula menghebahkan garis panduan kepada orang ramai bagaimana untuk membendung, merawat dan mengawal penyakit Covid 19. Pentingnya untuk tidak menimbulkan suasana panik dikalangan semua masyarakat, beberapa SOP diperkenalkan dan dilaksanakan. Komunikasi visual mula memainkan peranan penting terhadap pelaksanan SOP yang sarankan oleh kerajaan.

Masyarakat pada umumnya tertanya-tanya bagaimanakah gambaran virus Covid 19. Imej grafik telah banyak membantu berkomunikasi secara visual menjelaskan gambaran bagaimanakan rupa bentuk virus Covid 19. Visual imej grafik virus Covid 19 telah diperkenalkan, diperjelaskan dan dihebahkan kepada orang ramai bagi menggambarkan bahawa inilah rupa bentuk virus Corona atau dikenali sebagai virus Covid 19 seperti yang ditunjukkan dalam Rajah 2. 


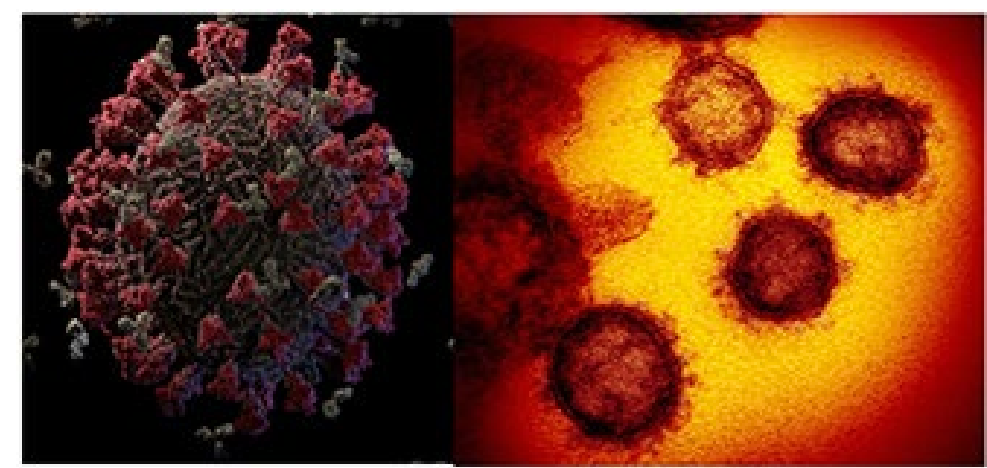

Rajah 2: Visual Visual Corona Virus/Covid 19

Melalui komunikasi visual, orang ramai berupaya mengenali rupa bentuk virus dan pandemik Covid 19 yang menakutkan ini. Rajah 3 memperlihatkan simbol, lambang dan juga warna merah digunakan sebagai imej grafik bagi menggambarkan Covid 19. Imej grafik tersebut direka berdasarkan daripada visual asal Covid 19 yang bertujuan agar ia lebih mudah dikenali dan mudah untuk dijelaskan kepada orang ramai mengenai virus ini.
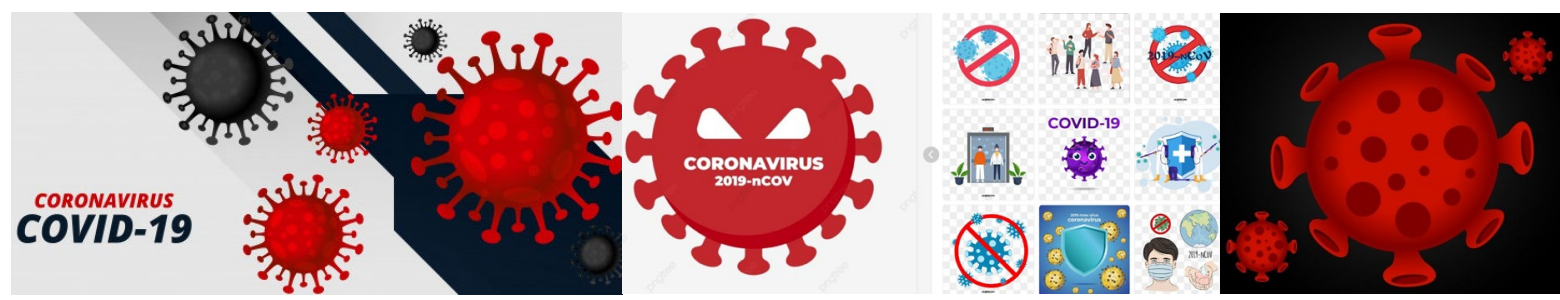

Rajah 3: Simbol dan lambang visual Corona Virus/Covid 19

\subsection{Komunikasi Visual Berperanan Untuk Mendidik}

Ilustrasi, imej grafik, logo dan info grafik mula membanjiri ruang platform media cetak dan media massa. Lambakan komunikasi visual samada di televisyen, suratkhabar, majalah, media sosial, poster dan sebagainya dihebahkan semata-mata untuk mengajar orang ramai apa yang patut dilakukan dan apa yang tidak patut dilakukan. Pada masa ini betapa pentingnya komunikasi visual terhadap semua lapisan masyarakat tidak kira muda atau tua didedahkan dengan informasi-informasi visual agar orang ramai semua dapat memahami segala SOP yang harus dipatuhi disetiap masa dan di setiap tempat. Sebagai contohnya, info grafik visual mengenai pemakaian pelitup muka (facemask) dengan betul untuk pelbagai peringkat umur. Ia seperti yang ditunjukkan dalam Rajah 4. Bukan hanya jabatan-jabatan kerajaan malahan NGO juga turut membantu mengeluarkan garis-garis panduan tersebut agar dapat mendidik orang ramai mengenai informasi Covid 19 yang perlu diketahui.

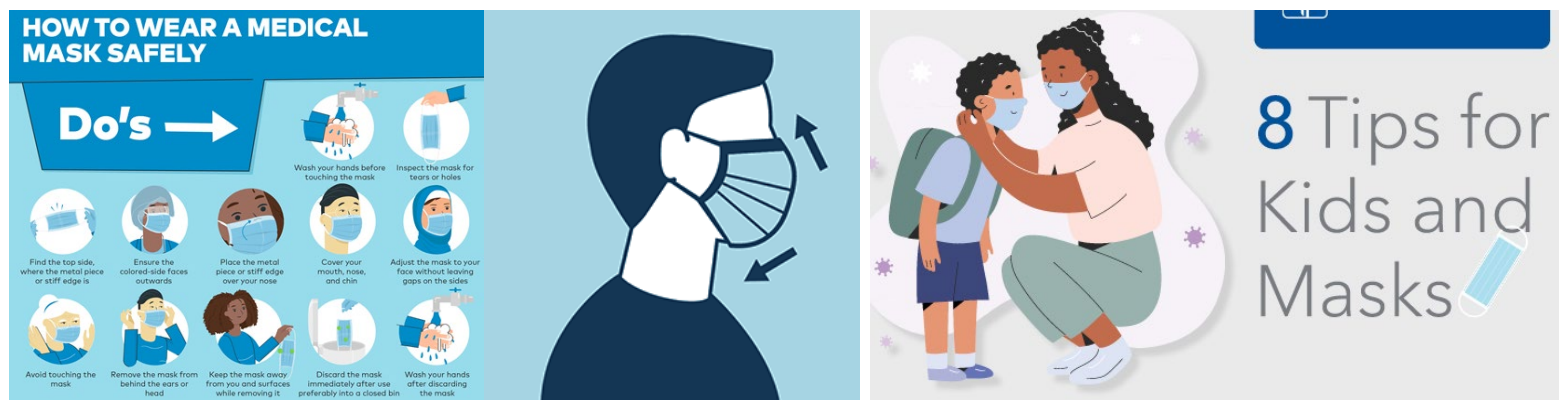

Rajah 4: Info grafik pemakaian pelitup muka 


\subsection{Komunikasi Visual Berperanan Untuk Memudahkan Kefahaman}

Selagi pandemik Covid 19 belum berakhir, selagi itulah orang ramai perlu didedahkan dengan informasi semasa. Kefahaman mengenai visual membantu mengurangkan tekanan 'stress' orang ramai dalam menjalani kehidupan seharian dan hari-hari yang bakal ditempuhi. Apabila terjadinya keperluan dan ketetapan orang ramai untuk duduk di rumah (semasa PKP) orang ramai perlu faham apakah SOP yang harus dipatuhi. Maklumat perlu sampai kepada orang ramai dengan tepat dan sepantas yang mungkin. Justeru itu, komunikasi visual berperanan penting untuk membantu menyalurkan maklumat dengan berkesan.

Komunikasi visual terutamanya semasa Covid 19 berupaya mempercepatkan lagi kefahaman mengenai apa yang hendak disampaikan oleh Kementerian Kesihatan serta Majlis Keselamatan Negara. Rajah 5 menunjukkan contoh kepentingan visual dalam membantu untuk berkomunikasi dengan lebih berkesan bagi memudahkan kefahaman orang ramai mengenai pematuhan dan panduan ketika menjalankan kehidupan harian. Visual yang dipamerkan ini amat mudah difahami yang mana maksudnya menjelaskan keperluan penjarakkan sosial perlu diamalkan.

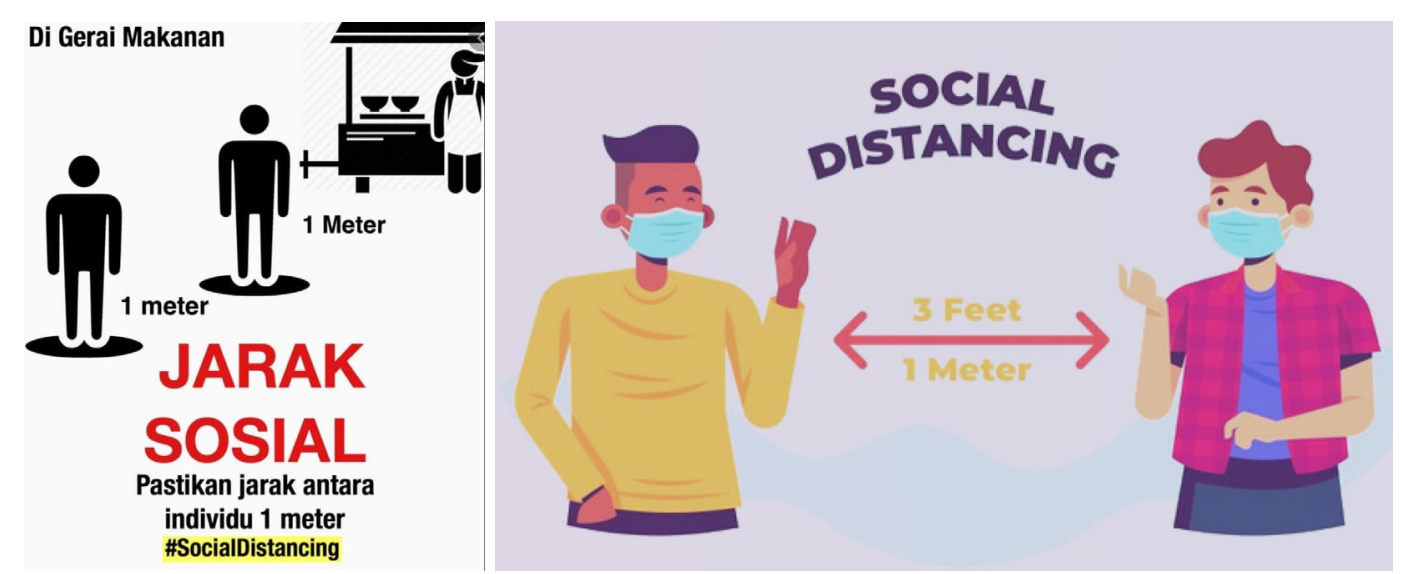

Rajah 5: Komunikasi visual penjarakkan sosial

Rajah 6 pula menunjukkan visual mengenai aturcara kaedah-kaedah amalan kebersihan dan jarak sosial jika bergejala. Visual yang ditunjukkan ini adalah bertujuan untuk memudahkan orang ramai memahami dengan lebih cepat dan jelas. Susun atur visual memberi gambaran yang jelas mengenai situasi sebenar yang perlu dipraktikkan semasa pandemik Covid 19. Ia mudah untuk difahami oleh semua peringkat umur.

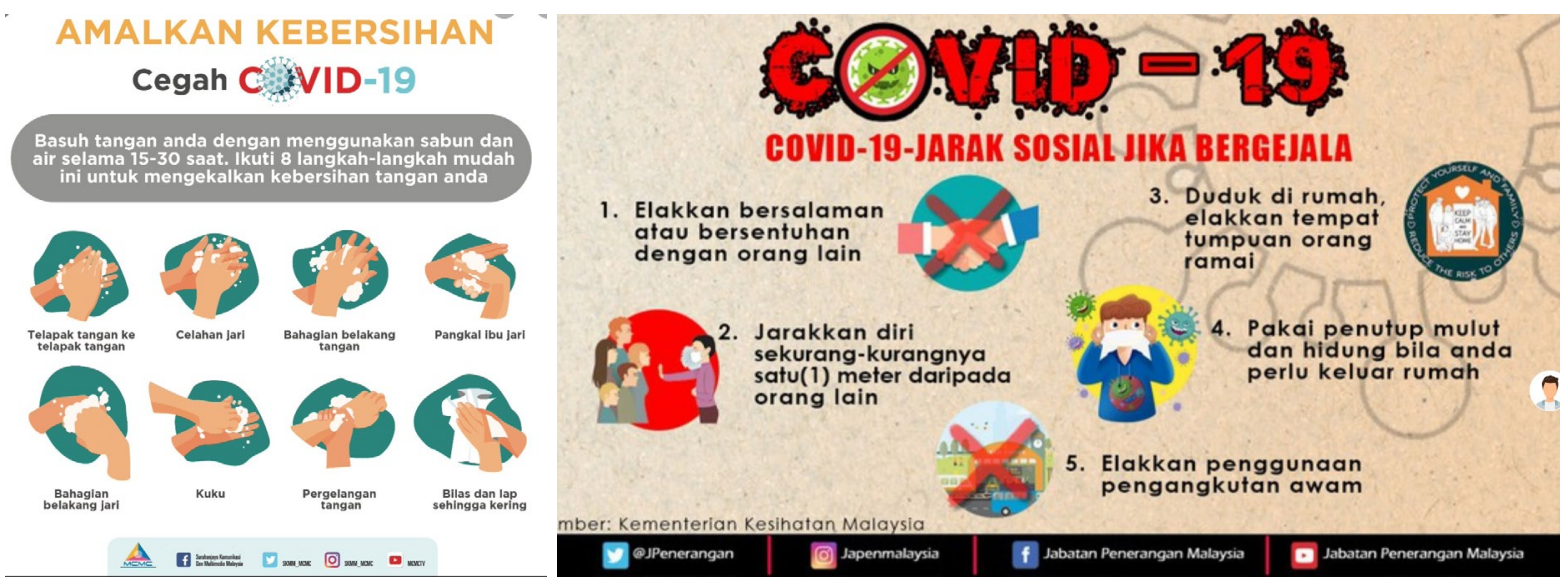

Rajah 6: Komunikasi visual aturcara kaedah amalan kebersihan dan jarak sosial 
Secara kesimpulannya pandemik Covid 19 telah memberi tamparan luar jangkaan kepada seluruh negara. Ia memberi suatu cabaran yang hebat terhadap aspek komunikasi. Ketika setiap negara bergelut untuk memerangi pandemik Covid 19, aspek komunikasi menjadi elemen terpenting bagi setiap individu di setiap situasi, setiap masa dan setiap tempat. Orang ramai dilanda kekeliruan dan kebingungan dengan situasi ini. Justeru itu, komunikasi visual berperanan penting membantu menyampaikan maklumat dan informasi penting mengenai Covid 19. Perhatian serius perlu diambil kira terhadap aspek komunikasi visual agar ia berupaya untuk memberi peranan yang berkesan. Tidak dapat dinafikan bahawa komunikasi visual juga turut menjadi penyumbang terpenting terhadap pengawalan pandemik Covid 19 selain daripada pengiktirafan dan pengorbanan daripada 'fronliners' seperti Kementerian Kesihatan dan Majlis Keselamatan Negara.

\section{RUJUKAN}

David, C., \& Paul, H. (2016). Communication in history: Technology, Culture, Society. Routledge Pearson, Education Inc, New York. USA

Faridah Ibrahim, Tika Nuraeni, Fauziah Ahmad, Chang Peng Kee \& Normah Mustaffa (2012). Bahasa komunikasi visual dan pengantaraan produk: Satu analisis semiotik. GEMA Online ${ }^{\mathrm{TM}}$ Journal of Language Studies 257, Volume 12(1), January 2012

Nur Idayu Yusi (2017). Pelaksanaan literasi dalam pengajaran dan pembelajaran. Pendeta Journal of Malay Language, Education and Literature, Jilid 8, 2017/ISSN 1823-6812 (66-71)

Peter, F. D. (2017). Hieroglyph: Writing character. Dicapai dari https://www.britannica.com/topic/hieroglyphic-writing (7 Ogos 2020)

Syerif Nurhakim (2015), Dunia komunikasi dan gadget: Evolusi alat komunikasi, menjelajah jarak dengan gadget. Penerbit Bestari, Jl. Waru, Jakarta 
Idealogy Journal

Volume 5 Issue 22020

溇 IDEALOGY

JOURNAL 